International Research Journal of Engineering, IT \& Scientific Research
Available online at https://sloap.org/journals/index.php/irjeis/
Vol. 8 No. 1, January 2022, pages: 7-16
ISSN: 2454-2261
https://doi.org/10.21744/irjeis.v8n1.2039

\title{
Structure Analysis of Building Functions Transition on the Earthquake Area Five Reviewed from Costs and Time Schedule
}

\author{
I Wayan Suasira ${ }^{a}$ \\ I Wayan Intara ${ }^{\text {b }}$ \\ I Ketut Sutapa ${ }^{c}$ \\ I Made Anom Santiana ${ }^{d}$ \\ I Gede Sastra Wibawa ${ }^{\mathrm{e}}$ \\ I Made Tapa Yasa ${ }^{\mathrm{f}}$
}

\section{Article history:}

Submitted: 18 November 2021

Revised: 27 December 2021

Accepted: 09 January 2022

\section{Keywords:}

building functions;

costs;

earthquake;

time schedule;

transition;

\begin{abstract}
The purpose of this study is to determine the dimensions and reinforcement of structure, cost, and schedule due to the transition structure of the building function. The structural transition of building functions is carried out in the earthquake area five with the classification of soft and hard soils. The building used as a research model is a 3-story residence on Nuansa Utama Selatan Street number 3, Jimbaran, Bali. The planning of this building will be converted into office buildings and shophouse on the $2^{\text {nd }}$ and $3^{\text {rd }}$ floors functioning as a warehouse in the earthquake area five in Bali with the classification of soft and hard soil that will be analyzed using SAP 2000 program so that the structural dimensions are used as a reference in the creation of costs, and schedule obtained using Microsoft Project program. The analysis of structure shows that the structure of a residential house on hard soil has the dimensions and reinforcement of the smallest structure. The ratio of structural reinforcement in the transition of structure functions from residential house to office on hard soil by $1.32 \%$ with the lowest structure cost ratio by $1.80 \%$ and schedule of the structure by $3.80 \%$.
\end{abstract}

International research journal of engineering, IT \& scientific research (C) 2022. This is an open access article under the CC BY-NC-ND license (https://creativecommons.org/licenses/by-nc-nd/4.0/).

\section{Corresponding author:}

I Wayan Suasira,

Department of Civil Engineering, Bali State Polytechnic, Indonesia.

Email address: suasira@gmail.com

a Department of Civil Engineering, Bali State Polytechnic, Indonesia

b Department of Civil Engineering, Bali State Polytechnic, Indonesia

${ }^{c}$ Department of Civil Engineering, Bali State Polytechnic, Indonesia

${ }^{d}$ Department of Civil Engineering, Bali State Polytechnic, Indonesia

e Department of Civil Engineering, Bali State Polytechnic, Indonesia

f Department of Civil Engineering, Bali State Polytechnic, Indonesia 


\section{Introduction}

In the development of infrastructure, which is increasingly rapid causing need land in the development as houses, hotels, apartments, offices, etc. The rise of development has an impact to do the construction of multi-story buildings in saving existing land (Doniyor \& Khabibulla, 2021). In planning a multi-story building there must be factors that must be considered such as the function of the building, safety, strength, comfort for the user, and certainly must be economical.

The transition of building functions that is rife in Badung now has an impact on the change in function from private buildings to commercial buildings (Hölscher et al., 2018; Boisgontier \& Cheval, 2016). This becomes an important issue for building owners and construction parties about the transition of building functions who carried out because it has been mentioned in SNI-1727-2013 concerning "Minimum Loads for Building Design and Other Structures" (Badan Standarisasi Nasional, 2013), that the living load of each building is different according to the function of the building. The phenomenon that often occurs that many construction parties do not pay attention to structural calculations in changing the function of buildings from private buildings to the public building. This is certainly very influential in building structures in both dimensions and reinforcement of structures due to different loads. The planning about the transition of building functions must of course have been thought out beforehand by the construction party to improve the safety of the construction (Oral et al., 2004; Babič \& Dolšek, 2016; Todorovska \& Trifunac, 2008). So that undesirable things do not occur in terms of the strength of the building structure to support the load after changing the function of the building. Building construction has the risk of damage even destruction from the earthquake. Bali is an area that has a high risk of earthquakes because Bali is located at the confluence of three plates namely the Australian plate, Eurasian plate and Pacific plate, so that it has high volcanic and earthquake activity (Gupta \& Khan, 2021). In SNI 03-1726-2002 concerning "Procedures for Planning Earthquake Resilience for Buildings" (Badan Standarisasi Nasional, 2002), states that there are six earthquake areas which are divided in Indonesia. Based on the image of the Indonesian earthquake areas, Bali is one of the most vulnerable earthquake areas, namely earthquake areas four and five.

Therefore, this research is conducted to minimize the risk of losses due to earthquakes that occur mainly for high rise buildings. The role of construction parties is very important in exploring earthquake planning rules on building structures so that when an earthquake occurs the building does not collapse or only minimal damage to the architecture section (Hamdi, 2016). Then, do the planning of analysis of the structural reinforcement dimensions caused by the transition of building functions in the earthquake area five with different soil classifications (Ghobarah, 2001; McGuire, 2001; Fiedrich et al., 2000). In addition, it is necessary to determine the cost and time of proper and accurate implementation of the building construction being analyzed. So, as to produce a building that is strong, stable, rigid, safe, comfortable, and economical.

\section{Materials and Methods}

The method used is the analytical method that is an analysis of the strength of the structure of the building based on SNI 03-1726-2002, SNI 03-2847-2002, SNI-1727-2013, and the Indonesian Load Regulations for Buildings in 1983. Buildings are used as the model study was a 3-storey residence on Nuansa Utama Selatan Street number 3, Jimbaran, Bali. The planning of this building will be built on the location of the 5th earthquake area in Bali with the classification of soft and hard soils. The transition of building functions as an office building and shophouses on the 2nd and 3rd floors to function as warehouses.

Secondary data collection in the form of soil test data, SNI regulations, shop drawing, material and equipment prices in 2019, labor prices in 2019, and AHSP in 2019. While primary data collection is in the form of time schedule, costs, and technical specifications (Xue et al., 2022; Feng et al., 2010). Analysis of structural modelling using SAP 2000 Version 14 application program with live load in accordance with each type of building in the soft and hard soil classification of the earthquake area 5. The dimensions of reinforcement resulting from SAP 2000 Version 14 modeling are used as a reference in the preparation of the cost, and the time schedule is obtained using the Microsoft Project program. The variables in this research are the Transition of Building Functions (X1), Earthquake Area (X2), and Soil Classification (X3) as Independent Variables. While Cost (Y1) and Time Schedule (Y2) as Dependent Variables. 


\section{Results and Discussions}

Planning structure data

Material type planning data used are as follows:

- Concrete

$\begin{array}{ll}\text { Specific gravity } & =2400 \mathrm{~kg} / \mathrm{m}^{3} \\ \text { Quality of Concrete (f'c) } & =25 \mathrm{MPa} \\ \text { Modulus of Elasticity } & =4700 \sqrt{f^{\prime} c} \mathrm{MPa} \\ \text { Reinforcing Steel } & \\ \text { Specific gravity } & =7850 \mathrm{~kg} / \mathrm{m}^{3} \\ \text { Modulus of Elasticity } & =200000 \mathrm{MPa} \\ \text { Fy Deformed Bar } & =400 \mathrm{MPa} \\ \text { Fy Plain Bar } & =240 \mathrm{MPa} \\ \text { Truss Steel } & \\ \text { Specific gravity } & =7850 \mathrm{~kg} / \mathrm{m}^{3} \\ \text { Modulus of Elasticity } & =200000 \mathrm{MPa} \\ \text { Fy Truss Steel } & =550 \mathrm{MPa}\end{array}$

\section{Load Data}

- Dead Load

Dead load is the burden due to the weight of the structure and additional dead load on structures that are permanents such as columns, beams, and floor plates. While the additional dead load on structures such as masonry walls, ceiling, and hangers, metal tile roof with battens, mortar, ceramics, and MEP. Dead load that works on the building structure are as follows:
Reinforced concrete
$=2400 \mathrm{~kg} / \mathrm{m}^{3}$
A pair bricks of half stone
$=250 \mathrm{~kg} / \mathrm{m}^{2}$
Mortar one $\mathrm{cm}$ thick
$=21 \mathrm{~kg} / \mathrm{m}^{2}$
Ceramics floor one $\mathrm{cm}$ thick $\quad=24 \mathrm{~kg} / \mathrm{m}^{2}$
Ceiling and hangers $\quad=18 \mathrm{~kg} / \mathrm{m}^{2}$
Metal tile roofs + battens $\quad=5 \mathrm{~kg} / \mathrm{m}^{2}$
MEP
$=25 \mathrm{~kg} / \mathrm{m}^{2}$

- Live Load

Live load is load whose position can change in the structure of a building and not permanent who happens as occupancy or use of a building. The live load given to the floor plates in accordance with the function of each building can be seen in SNI-1727-2013 in table 4.3. While the roof's living load is obtained based on the Indonesian Load Regulations for Buildings in 1983 in article 3.2.

- Spectrum Response Earthquake Load

Earthquake load is a load that works on building structures caused by the influence of ground movements that occur due to the earthquake. In the earthquake map of Indonesia, Bali is included in the earthquake areas four and five so the reduction factor (R) value by 5 is in accordance with SNI-1726-2012 which can be seen in table 9 in article 7.2.2.

In determining the direction of the earthquake impact plan on building structures, the main direction of earthquake load must be considered $100 \%$ effective and must be considered to occur simultaneously with the effect of earthquake load the perpendicular direction in the main direction with effectiveness by $30 \%$ (SNI 03 1726-2002 article 5.8.2).

The planning of earthquake spectrum response for area 5 based on SNI 03-1726-2002 article 4.7.4. In the graph, $\mathrm{C}$ is an earthquake response factor expressed in an acceleration of gravity, while $\mathrm{T}$ is the natural vibration time of the building structure expressed in seconds.

\section{Soil Data}

The results of the soil investigation are used to support the analysis of building structure modeling data in the earthquake area 5 with different classification soils using a Cone Penetration Test. The following is the carrying capacity of the land-based on the results of the soil investigation.

Suasira, I. W., Intara, I. W., Sutapa, I. K., Santiana, I. M. A., Wibawa, I. G. S., \& Yasa, I. M. T. (2022). Structure analysis of building functions transition on the earthquake area five reviewed from costs and time schedule. International Research Journal of Engineering, IT \& Scientific Research, 8(1), 7-16. https://doi.org/10.21744/irjeis.v8n1.2039 
- Soft Soil

The analysis of soil bearing capacity data obtained through the Cone Penetration Test. The depth of hard soil and average groundwater level at the test location has a depth of 19 meters with a carrying capacity of $40 \mathrm{~cm}$ diameter bore pile. The minimum carrying capacity of the bore pile that is the value of the carrying capacity of the bore pile permit at point S3 by 74.84 tons.

Table 1

Results of cone penetration test data in S3 area soft soil

\begin{tabular}{ccccccc}
\hline \multicolumn{7}{c}{ Depth of Pile Penetration Df $=19 \mathrm{~m}$} \\
\hline Dia. Pile $\emptyset(\mathrm{cm})$ & $4 \times \varnothing(\mathrm{cm})$ & $q c(\mathrm{~kg} / \mathrm{cm} 2)$ & $A b(\mathrm{~cm} 2)$ & $U(\mathrm{~cm})$ & $c(\mathrm{~kg} / \mathrm{cm})$ & $Q s p($ ton $)$ \\
\hline 25 & 100 & 166.67 & 490.87 & 78.54 & 200 & 30.41 \\
30 & 120 & 166.67 & 706.86 & 94.25 & 200 & 43.04 \\
35 & 140 & 166.67 & 962.11 & 109.96 & 200 & 57.85 \\
40 & 160 & 166.67 & $1,256.64$ & 125.66 & 200 & 74.84 \\
45 & 180 & 166.67 & $1,590.43$ & 141.37 & 200 & 94.01 \\
50 & 200 & 166.67 & $1,963.50$ & 157.08 & 200 & 115.37 \\
100 & 400 & 166.67 & $7,853.98$ & 314.16 & 200 & 448.90 \\
\hline
\end{tabular}

Source: Soil Testing Data on Sunset Road, Kuta

- Hard Soil

The data analysis of the carrying capacity of the soil obtained through the Cone Penetration Test is the depth of hard soil from the surface of the Cone Penetration Test. The depth of hard soil from the surface of the Cone Penetration Test has a depth of 1.50 meters with a land permit voltage by $6.25 \mathrm{~kg} / \mathrm{cm}^{2}$. The foundation used is the foundation of reinforced concrete, where the width of the foundation is calculated based on the number of forces borne by the foundation.

Table 2

Results of Cone Penetration Test Data in S1 Area Hard Soil Soft Soil

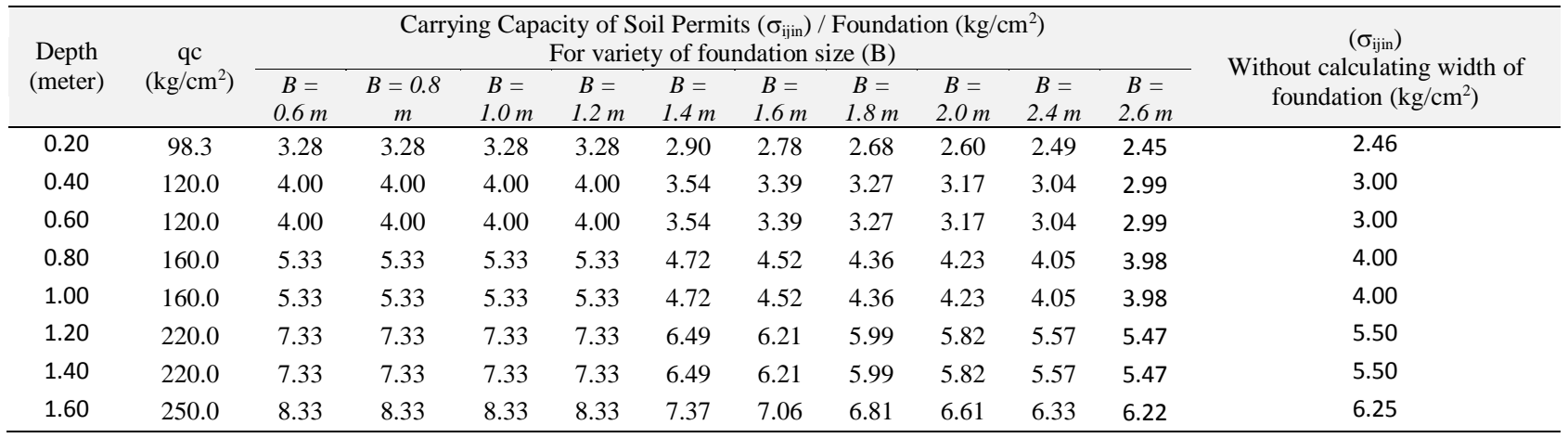

Source: Soil Testing Data on Desa Ungasan, Kuta Selatan

\section{Analysis of SAP 2000 Version 14}

The results of structural modeling analysis in SAP 2000 Version 14 will be obtained reinforcement area on tie beams, columns, and beams in each building with the classification of soft and hard soils. Detailed requirements for reinforcement based on SNI-03-2847-2002 article 9.

- Tie Beam Reinforcement

The minimum longitudinal reinforcement diameter of the tie-beam using a diameter iron of $13 \mathrm{~mm}$ and the minimum stirrup reinforcement diameter using a diameter iron of $8 \mathrm{~mm}$. Side reinforcement using a diameter iron of $10 \mathrm{~mm}$ considering the height of tie-beam $\geq 30 \mathrm{~cm}$. 
- Column Reinforcement

The minimum longitudinal reinforcement diameter of the column using a diameter iron of $13 \mathrm{~mm}$ and the minimum stirrup reinforcement diameter using a diameter iron of $8 \mathrm{~mm}$.

- Beam Reinforcement

The minimum longitudinal reinforcement diameter of the beam using a diameter iron of $13 \mathrm{~mm}$ and the minimum stirrup reinforcement diameter using a diameter iron of $8 \mathrm{~mm}$. Side reinforcement using a diameter iron of $10 \mathrm{~mm}$ considering the height of beam $\geq 30 \mathrm{~cm}$.

\section{Analysis of Floor Plate Planning}

The diameter of the residential house and office floor plate reinforcement uses a diameter iron of $8 \mathrm{~mm}$, while the diameter of the shop house floor plate reinforcement uses a diameter iron of $10 \mathrm{~mm}$ with the classification of soft and hard soils.

\section{Analysis of Foundation Planning}

The foundation on soft soil is planned to use a bore pile foundation with a depth of 19 meters, while the foundation on hard soil is planned to use a footplate foundation. The following are the general provisions of the foundation.

Quality of Concrete (f'c) $=25 \mathrm{MPa}$

Fy $\quad=400 \mathrm{MPa}$

$\gamma_{\text {soil }} \quad=1600 \mathrm{~kg} / \mathrm{m} 3$

$\gamma_{\text {reinforced concrete } \quad=2400 \mathrm{~kg} / \mathrm{m} 3}$

Concrete cover $\quad=75 \mathrm{~mm}$

The minimum longitudinal reinforcement diameter of foundation using a diameter iron of $10 \mathrm{~mm}$, the thickness of the footplate foundation $30 \mathrm{~cm}$, and the thickness of the pile cap foundation $50 \mathrm{~cm}$. The carrying capacity of the soil is adjusted to the type of land on which the building will be built.

The steps for planning a bore pile foundation are as follows:

a) Calculate the carrying capacity of piles pressure permission

b) Calculate the piles number

c) Determine the poer foundation dimensions

d) Calculate the efficiency of the pile groups

e) Calculate the carrying capacity of pile groups

f) Control the total vertical load and poer weight

g) Calculate the maximum load of piles in the pile groups

h) Control the shear stress of the puncher

i) Control the moment of foundation

j) Poer reinforcement

While the steps of footplate foundation planning are as follows:

a) Determine the dimensions of the foundation

b) Calculate the vertical load which is bestowed foundation to the ground

c) Control the tension of the soil under the foundation

d) Control of one-way shear stress

e) Control of two-way shear stress

f) Control the moment of foundation

g) Calculate the reinforcement of the foundation

Structure reinforcement comparison of each building with the classification of soft and hard soils can be seen in the following table.

Suasira, I. W., Intara, I. W., Sutapa, I. K., Santiana, I. M. A., Wibawa, I. G. S., \& Yasa, I. M. T. (2022). Structure analysis of building functions transition on the earthquake area five reviewed from costs and time schedule. International Research Journal of Engineering, IT \& Scientific Research, 8(1), 7-16. https://doi.org/10.21744/irjeis.v8n1.2039 
Table 3

Comparison of structure reinforcement

\begin{tabular}{llll}
\hline No & Building Functions & Soil Classification & Structure Reinforcement (unit) \\
\hline 1 & Residential House & Soft Soil & 287 \\
& & Hard Soil & 227 \\
2 & Office & Soft Soil & 300 \\
& & Hard Soil & 230 \\
3 & \multirow{2}{*}{ Shop House } & Soft Soil & 334 \\
& & Hard Soil & 247 \\
\hline
\end{tabular}

Source: Analysis Result

\section{Comparison of Structure Reinforcement}

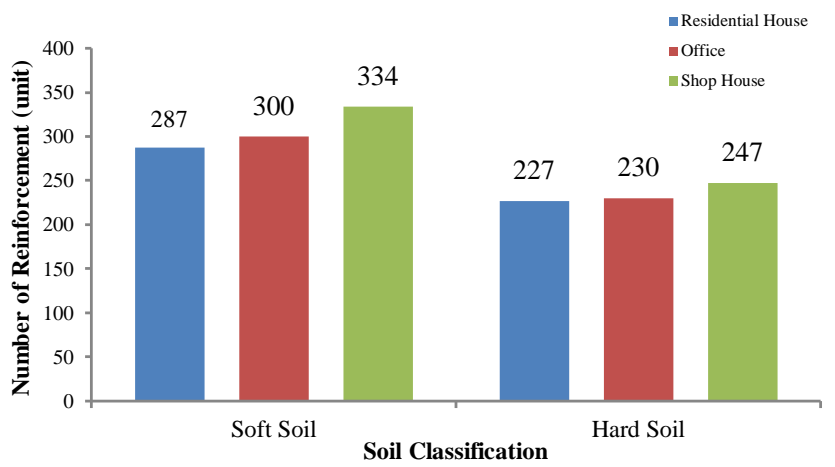

Figure 1. Comparison chart of structure reinforcement

\section{Cost Planning}

After the analysis of structural modeling, a calculation of the volume of structural work is carried out to be included in the cost budget plan. In addition to the need for the volume of work, in preparing the cost, it is also necessary to have unit price in the form of material prices, labor prices, and equipment prices. The total price obtained for each job by multiplying the volume of work and the price of the unit of work.

In preparing the costs, carefulness and accuracy are needed to minimize the swelling of prices and the cost of the forgotten work. So that obtain an effective and efficient cost budget plan.

- Labor Prices Data

The labor price is obtained from Bidang Cipta Karya of Public Works and Spatial Planning of Badung Regency in 2019. Labor costs are obtained by multiplying the price of each labor wage and the labor coefficient. The labor coefficient is obtained from the unit price analysis.

Table 4

Comparison of Structure Reinforcement

\begin{tabular}{clllr}
\hline No & Labor & Unit & \multicolumn{2}{l}{ Labor Prices } \\
\hline 1 & Worker & OH & $\mathrm{Rp}$ & $95.000,00$ \\
2 & Digger & OH & $\mathrm{Rp}$ & $110.000,00$ \\
3 & Mason & OH & $\mathrm{Rp}$ & $110.000,00$ \\
4 & Carpenter & $\mathrm{OH}$ & $\mathrm{Rp}$ & $110.000,00$ \\
5 & Farrier & $\mathrm{OH}$ & $\mathrm{Rp}$ & $110.000,00$ \\
6 & Foreman & $\mathrm{OH}$ & $\mathrm{Rp}$ & $120.000,00$ \\
7 & Overseer & $\mathrm{OH}$ & $\mathrm{Rp}$ & $130.000,00$ \\
\hline
\end{tabular}

Source: Bidang Cipta Karya in 2019 
- Material and Equipment Prices Data

The price of material and equipment is obtained from Bidang Cipta Karya of Public Works and Spatial Planning of Badung Regency in 2019. The price of each material and equipment is multiplied by the coefficient of material and equipment so that obtained the costs of material and equipment.

Table 5

Material and equipment prices

\begin{tabular}{|c|c|c|c|c|}
\hline \multirow{2}{*}{$\begin{array}{c}\text { No } \\
A\end{array}$} & Name of Material and Equipment & \multirow[t]{2}{*}{ Unit } & \multicolumn{2}{|c|}{$\begin{array}{c}\text { Material and } \\
\text { Equipment Prices }\end{array}$} \\
\hline & MATERIAL & & & \\
\hline \multirow[t]{5}{*}{1} & Wood & & & \\
\hline & Wood formwork & $\mathrm{m}^{3}$ & $\mathrm{Rp}$ & $3.900 .000,00$ \\
\hline & Dolken / Seawood $\varnothing 7.5-10 / 400 \mathrm{~cm}$ & btg & $\mathrm{Rp}$ & $12.000,00$ \\
\hline & Formwork oil & ltr & $\mathrm{Rp}$ & $8.600,00$ \\
\hline & Plywood 9 mm & lbr & $\mathrm{Rp}$ & $121.500,00$ \\
\hline \multirow[t]{2}{*}{2} & Stainless Steel Nails & & & \\
\hline & Nails $10 \mathrm{~cm}$ & $\mathrm{~kg}$ & $\mathrm{Rp}$ & $14.500,00$ \\
\hline \multirow[t]{4}{*}{3} & Ready Mix, Cement \& Concrete Water Mix & & & \\
\hline & Concrete K-300 & $\mathrm{m}^{3}$ & $\mathrm{Rp}$ & $1.006 .950,00$ \\
\hline & Gresik Cement $50 \mathrm{~kg}$ & zak & $\mathrm{Rp}$ & $69.000,00$ \\
\hline & Concrete Water Mix & ltr & $\mathrm{Rp}$ & 42,00 \\
\hline \multirow[t]{4}{*}{4} & Sand \& Gravel & & & \\
\hline & Concrete Coral 2/3 Ex. 4 per $2.75 \mathrm{M} 3$ & $\mathrm{~m}^{3}$ & $\mathrm{Rp}$ & $260.000,00$ \\
\hline & Concrete Sand / cast Ex. 4 per 2.75 M3 & $\mathrm{m}^{3}$ & $\mathrm{Rp}$ & $180.000,00$ \\
\hline & Sand & $\mathrm{m}^{3}$ & $\mathrm{Rp}$ & $170.000,00$ \\
\hline \multirow[t]{5}{*}{5} & Rebar & & & \\
\hline & Rebar & $\mathrm{kg}$ & $\mathrm{Rp}$ & $10.500,00$ \\
\hline & Concrete wire & $\mathrm{kg}$ & $\mathrm{Rp}$ & $16.000,00$ \\
\hline & Tremie Pipe and Protective Casing & Ls & $\mathrm{Rp}$ & $121.000,00$ \\
\hline & Oil + Solar & Ls & $\mathrm{Rp}$ & $35.850,00$ \\
\hline \multirow[t]{4}{*}{$B$} & EQUIPMENT & & & \\
\hline & Crawler Crane & Jam & $\mathrm{Rp}$ & $987.500,00$ \\
\hline & Drilling Machine & Jam & $\mathrm{Rp}$ & $50.000,00$ \\
\hline & Equipment & & $\mathrm{Rp}$ & $20.000,00$ \\
\hline
\end{tabular}

Source: Bidang Cipta Karya in 2019

- Structural Work Volume

The volume of work is calculated completely and accurately so that no work is forgotten. The volume of work is calculated based on the reinforcement detail drawing and structure floor plan contained in appendix 4.

- Cost Budget Plan

After obtaining the unit price of work and the volume of structure work, then the comparison of the cost of the structure of each building with the classification of soft and hard soils can be seen in the following table.

Table 6

Comparison of Cost Budget Plan

\begin{tabular}{llll}
\hline Building Functions & Soil Classification & \multicolumn{2}{l}{ Cost Budget Plan } \\
\hline Residential House & Soft Soil & $\mathrm{Rp}$ & $804.801 .672,82$ \\
& Hard Soil & $\mathrm{Rp}$ & $513.656 .825,09$ \\
Office & Soft Soil & $\mathrm{Rp}$ & $830.570 .658,28$ \\
& Hard Soil & $\mathrm{Rp}$ & $522.887 .702,57$ \\
Shop House & Soft Soil & $\mathrm{Rp}$ & $950.823 .629,37$ \\
& Hard Soil & $\mathrm{Rp}$ & $575.524 .380,15$ \\
\hline
\end{tabular}

Source: Analysis Result

Suasira, I. W., Intara, I. W., Sutapa, I. K., Santiana, I. M. A., Wibawa, I. G. S., \& Yasa, I. M. T. (2022). Structure analysis of building functions transition on the earthquake area five reviewed from costs and time schedule. International Research Journal of Engineering, IT \& Scientific Research, 8(1), 7-16. https://doi.org/10.21744/irjeis.v8n1.2039 


\section{Comparison of Cost Budget Plan}

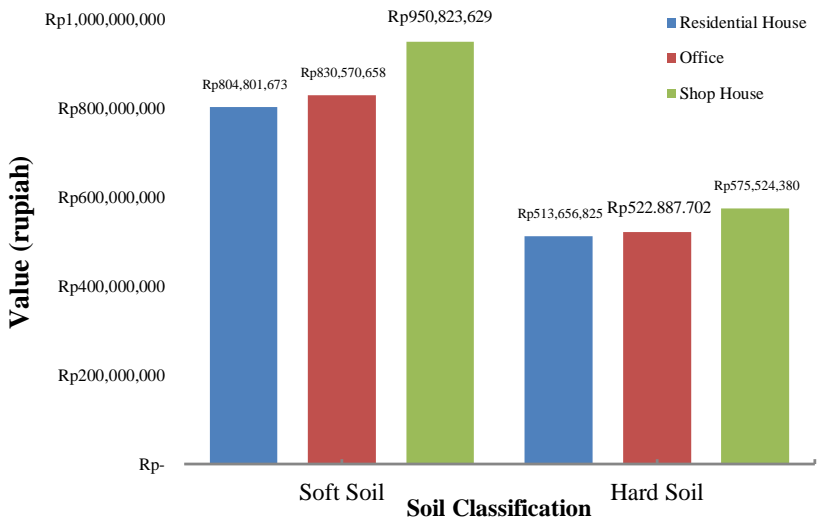

Figure 2. Comparison chart of cost budget plan

\section{Time schedule}

Time schedule of project using the Microsoft Project program. Analyzing the material, equipment, and labor needed in accordance with the volume of work, to produce the time schedule on the work carried out. Followed by predecessor planning so that the work is interconnected with each other. Time schedule comparison of each building with the classification of soft and hard soils can be seen in the following table.

Table 7

Comparison of time schedule plan

\begin{tabular}{llll}
\hline No & Building Functions & Soil Classification & Time Schedule (Week) \\
\hline 1 & Residential House & Soft Soil & 11 \\
& & Hard Soil & 7.9 \\
2 & Office & Soft Soil & 11.5 \\
& & Hard Soil & 8.2 \\
3 & \multirow{2}{*}{ Shop House } & Soft Soil & 13.2 \\
& & Hard Soil & 9 \\
\hline
\end{tabular}

Source: Analysis Result

\section{Comparison of Time Schedule}

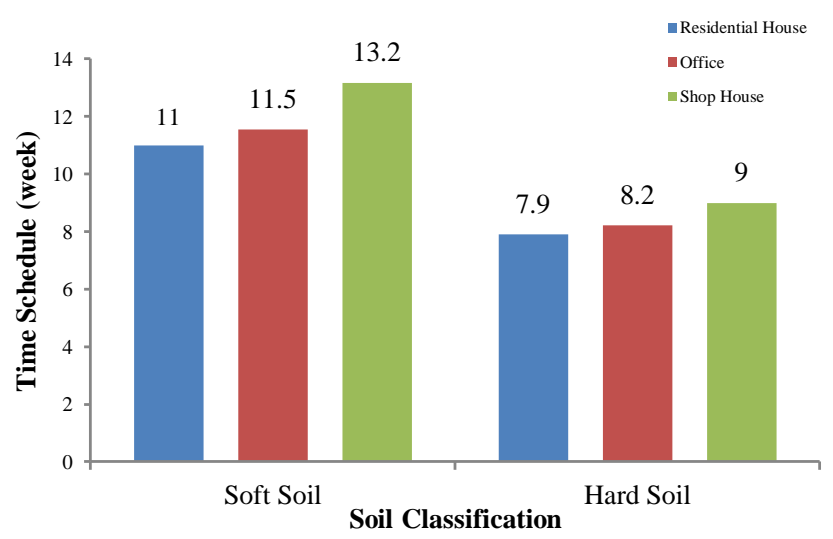

Figure 3. Comparison chart of time schedule 


\section{Conclusion}

Based on the results of the discussion that author, conclusion can be drawn from this study are as follows:

a) Based on the results of the analysis of structural modeling using SAP 2000 application with live load in accordance with the transition of building functions in the earthquake area 5 with the classification of soft and hard soils, the structural modeling dimensions of the residential house with classification hard soil obtained the smallest dimensions with the least structure reinforcement. While the structural modeling dimensions of the shop house with classification soft soil obtained the largest dimensions with the most structure reinforcement. Ratio of structure reinforcement in the transition of structure functions from residential house to office on soft soil by $4.53 \%$, ratio of structure reinforcement in the transition of structure functions from residential house to shop house with 2 nd and 3rd floors as warehouse on soft soil by $16.38 \%$, ratio of structure reinforcement in the transition of structure functions from residential house to office on hard soil by $1.32 \%$, and ratio of structure reinforcement in the transition of structure functions from residential house to shop house with 2 nd and 3rd floors as warehouse on hard soil by $8.81 \%$.

b) Comparison of Cost Budget Plan obtained in each structure of transition of building functions with the classification of soft and hard soils, namely ratio of structure cost in the transition of structure functions from residential house to office on soft soil by $3.20 \%$, ratio of structure cost in the transition of structure functions from residential house to shop house with 2 nd and 3rd floors as warehouse on soft soil by $18.14 \%$, ratio of structure cost in the transition of structure functions from residential house to office on hard soil by $1.80 \%$, ratio of structure cost in the transition of structure functions from residential house to shop house with 2 nd and 3rd floors as warehouse on hard soil by $12.04 \%$. So, it can be concluded that the lowest structure cost contained in structure comparison of the transition of functions from residential house to office on hard soil by $1.80 \%$, while the highest structure cost contained in structure comparison of the transition of functions from residential house to shop house with 2 nd and 3rd floors as warehouse on soft soil by $18.14 \%$.

c) Comparison of Time Schedule Plan obtained in each structure of transition of building functions with the classification of soft and hard soils using the Microsoft Project program, namely ratio of structure time schedule in the transition of structure functions from residential house to office on soft soil by $4.90 \%$, ratio of structure time schedule in the transition of structure functions from residential house to shop house with 2 nd and 3rd floors as warehouse on soft soil by $14.80 \%$, ratio of structure time schedule in the transition of structure functions from residential house to office on hard soil by $3.80 \%$, ratio of structure time schedule in the transition of structure functions from residential house to shop house with $2^{\text {nd }}$ and $3^{\text {rd }}$ floors as warehouse on hard soil by $10.01 \%$. So, it can be concluded that the most quickly structure time schedule contained in structure comparison of the transition of functions from residential house to office on hard soil by $3.80 \%$, while the longest structure time schedule contained in structure comparison of the transition of functions from residential house to shop house with $2^{\text {nd }}$ and $3^{\text {rd }}$ floors as warehouse on soft soil by $14.80 \%$.

\section{Conflict of interest statement}

The authors declared that they have no competing interests.

Statement of authorship

The authors have a responsibility for the conception and design of the study. The authors have approved the final article.

Acknowledgments

We are grateful to two anonymous reviewers for their valuable comments on the earlier version of this paper.

Suasira, I. W., Intara, I. W., Sutapa, I. K., Santiana, I. M. A., Wibawa, I. G. S., \& Yasa, I. M. T. (2022). Structure analysis of building functions transition on the earthquake area five reviewed from costs and time schedule. International Research Journal of Engineering, IT \& Scientific Research, 8(1), 7-16. https://doi.org/10.21744/irjeis.v8n1.2039 


\section{References}

Babič, A., \& Dolšek, M. (2016). Seismic fragility functions of industrial precast building classes. Engineering structures, 118, 357-370. https://doi.org/10.1016/j.engstruct.2016.03.069

Badan Standarisasi Nasional. (2002). Procedures for Planning Earthquake Resilience for Buildings, SNI 03-17262002, Jakarta: Badan Standarisasi Nasional,.

Badan Standarisasi Nasional. (2013). Minimum Loads for Building Design and Other Structures, SNI 1727:2013, Jakarta: Badan Standarisasi Nasional,.

Boisgontier, M. P., \& Cheval, B. (2016). The anova to mixed model transition. Neuroscience \& Biobehavioral Reviews, 68, 1004-1005. https://doi.org/10.1016/j.neubiorev.2016.05.034

Doniyor, P., \& Khabibulla, P. (2021). Theoretical research of mechanics of yarns in assembly winding machines. International Research Journal of Engineering, IT \& Scientific Research, 7(5), 193-202. https://doi.org/10.21744/irjeis.v7n5.1928

Feng, C. W., Chen, Y. J., \& Huang, J. R. (2010). Using the MD CAD model to develop the time-cost integrated schedule for construction projects. Automation in Construction, 19(3), 347-356. https://doi.org/10.1016/j.autcon.2009.12.009

Fiedrich, F., Gehbauer, F., \& Rickers, U. (2000). Optimized resource allocation for emergency response after earthquake disasters. Safety science, 35(1-3), 41-57. https://doi.org/10.1016/S0925-7535(00)00021-7

Ghobarah, A. (2001). Performance-based design in earthquake engineering: state of development. Engineering structures, 23(8), 878-884. https://doi.org/10.1016/S0141-0296(01)00036-0

Gupta, M., \& Khan, M. A. (2021). Advances in applications of non-destructive testing (NDT): a review. International Research Journal of Engineering, IT \& Scientific Research,7(3), 76-86. https://doi.org/10.21744/irjeis.v7n3.1003

Hamdi, F. (2016). Analisis dan Evaluasi Kekuatan Struktur Atas Gedung Fakultas Ekonomi dan Manajemen IPB Terhadap Faktor Gempa Berdasarkan SNI 1727: 2013.

Hölscher, K., Wittmayer, J. M., \& Loorbach, D. (2018). Transition versus transformation: What's the difference?. Environmental innovation and societal transitions, 27, 1-3. https://doi.org/10.1016/j.eist.2017.10.007

McGuire, R. K. (2001). Deterministic vs. probabilistic earthquake hazards and risks. Soil Dynamics and Earthquake Engineering, 21(5), 377-384. https://doi.org/10.1016/S0267-7261(01)00019-7

Oral, G. K., Yener, A. K., \& Bayazit, N. T. (2004). Building envelope design with the objective to ensure thermal, visual and acoustic comfort conditions. Building and Environment, 39(3), 281-287. https://doi.org/10.1016/S0360-1323(03)00141-0

Todorovska, M. I., \& Trifunac, M. D. (2008). Earthquake damage detection in the Imperial County Services Building III: analysis of wave travel times via impulse response functions. Soil Dynamics and Earthquake Engineering, 28(5), 387-404. https://doi.org/10.1016/j.soildyn.2007.07.001

Xue, X., Ai, X., Fang, J., Yao, W., \& Wen, J. (2022). Real-time schedule of integrated heat and power system: A multi-dimensional stochastic approximate dynamic programming approach. International Journal of Electrical Power \& Energy Systems, 134, 107427. https://doi.org/10.1016/j.ijepes.2021.107427 